\title{
A new perspective on sin in the age of globalisation: Analyses and reflections of $\sin$ in the case of nation- state building of the United States
}

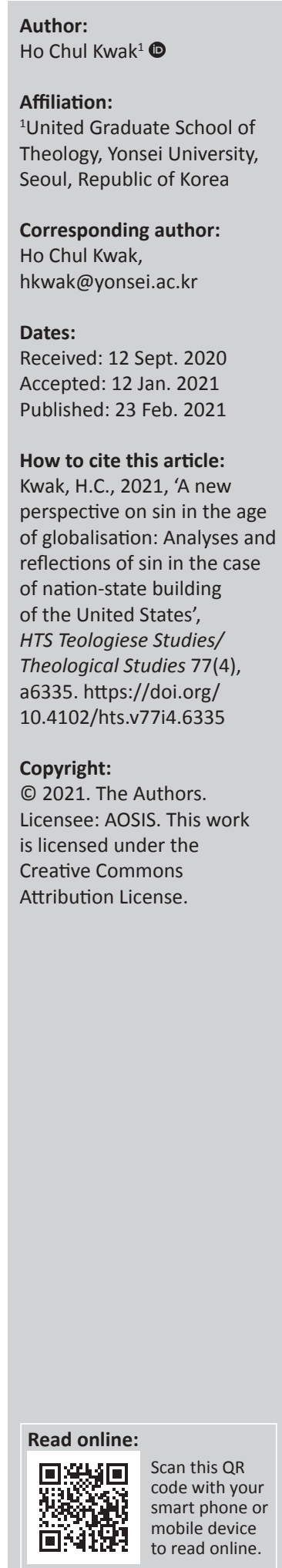

An interconnected and interdependent world in the age of globalisation invites Christianity to a different understanding of sin, which has been individualistically understood, because individualistic understanding of sin is impotent to address injustice or oppression caused by collective sins, wherein human beings have been collectively involved in. In order to overcome individualistic understanding of sin, this article is critically engaged in the concepts, such as concrete totality, which sees both individuality and socialness as constitutive parts of human beings, tyranny of collective identity through which oppression and injustice is carried out to unspecified others and retreat from truth to omnipotence, which is a concretised example of tyranny of collective identity in a nation-state building of the United States. Retreat from truth to omnipotence means that the United States covers its blamable history with relation to Native Americans and immigrants and justifies the discrimination and exclusion of others using untrue social, political, hygienic and economic reasons. Retreat from truth to omnipotence is not a temporal aberration but a constant repetition in the US history. To address discrimination and exclusion of others necessitates a new understanding of sin, that is, sin of human beings as concrete totality rather than an exclusively individualistic view of $\sin$.

Contribution: The article explores a necessity of emphasizing collective dimension of sin to address injustice and oppression caused by tyranny of collective identity in a globalizing world. It provides a theological foundation for building a welcoming political community to immigrants who have been unjustly discriminated or excluded.

Keywords: concrete totality; tyranny of collective identity; retreat from truth to omnipotence; sin; others; globalisation; immigrants.

\section{Introduction}

Globalisation challenges our individualistic understanding of sin. There are two distinguishable kinds of sin: personal sin and collective sin. Personal sin is related to private affairs, which seldom affect the life of others, whilst collective sin is connected to social matters that affect the life of associated individuals (Min 1989:107). Although there is personal sin for which an individual is solely responsible, such personal sin is in many ways connected to collective sin because he or she is thrown into a social web in which human beings are interconnected. In such an interconnected and interdependent world, exclusively individualistic understanding of sin is not only inappropriate but also destructive to Christian faith because it is impotent to address injustice or oppression in the world. Using a theological anthropology based on concrete totality, I will discuss that social and structural sins are ingrained in and inseparable from individual human beings. An anthropology seeing human beings as concrete totality also throws light on the concept of tyranny of collective identity. Tyranny of collective identity causes many structural sins, amongst which imperialism is a salient sin in our days. I will show concretised examples of imperialism from a nation-state building of the United States: the trajectory of retreat from truth to omnipotence throughout its history. Retreat from truth to omnipotence means that the US covers its blamable history with relation to Native Americans and immigrants and justifies their exclusion using untrue social, political, hygienic and economic reasons. Retreat from truth to omnipotence is not a temporal aberration in the history of the United States but a constant repetition of the US history, serving its tyranny of collective identity. The history of the United States reveals concretised tyranny of collective identity through retreat from truth to omnipotence. To address the injustice and oppression caused by tyranny of collective identity necessitates a new perspective on $\sin$ as sin of concrete totality rather than an exclusively individualistic understanding of sin. 


\section{Inadequacy of individualistic view of sin in the age of globalisation}

Globalisation has brought about many changes in this world. There are various opinions on globalisation, but Steger (2003:9-12) pointed out some thematic overlap in diverse scholarly explanations on globalisation, asserting that an overlapping theme of globalisation is social relations and activities that are being created, multiplied, expanded, stretched, intensified and accelerated. Such lively social interaction increases and intensifies social interconnections and interdependencies. The intensified and increased interdependencies have both good and bad influence on those who are in such intensified interdependent relationship. On the one hand, intensified interdependence facilitates mutual cooperation, because such mutual cooperation will benefit all parties in the intensified interdependent relationship. If all parties of the intensified interdependent relationship are equal and recognise equal human rights, the intensified relationship will probably result in mutual cooperation. On the other hand, however, intensified interdependence may worsen exploitative relationship between the powerful and the powerless. Because of intensified interdependence, the powerless have difficulty in liberating themselves from the powerful. If there are uneven relationships in intensified interdependent relationships and equal human rights of all parties are not recognised, there would be disastrous result from such intensified interdependence. The latter case is what I am concerned about. In reality, there are more uneven relationships amongst people than equal ones. Intensified interdependence probably makes uneven relationships worse and worse. The widening gap between haves and have-nots is a proof of worsening uneven relationships. It is well known that the total number of the poor is increasing whilst that of the wealthy is decreasing. In other words, a small number of people increase their wealth and power, whilst an overwhelming majority becomes poorer and more powerless. In this sense, globalisation ushers us into a world of worsening inequity.

Such an understanding of globalisation, intensifies interdependence and challenges our understanding of sin. Sin is a state of a human being estranged from God, from other fellow human beings and nature. Sin is a relational concept that reveals brokenness between God and a human being, between an individual and her fellow human beings and between human beings and nature. Because of broken relationship with God, a human being is unable to lead a healthy and sound life both spiritually and socially, indulging in domination of others. Although I accept that there is personal sin, which is about broken relationship with God and which does not affect lives of others and whose absolution is crucial for Christian faith, such absolution is meaningless as long as a saved Christian brings no peace to his or her fellow citizens and nature, ignoring precarious lives of the vulnerable. Whilst an individual focuses on absolution of his or her personal sin, he or she is prone to ignore an interdependent dimension of sin. We are accustomed to understanding sin exclusively individualistically. Understanding sin from an individualistic perspective, we regard $\sin$ as $\sin$ of an individual or sin of an immediate group. We have such a narrow-sighted understanding of sin because we think ourselves as isolated, ontological beings. As an isolated, ontological being, he could not see the effect of his act on those who are in intensified interdependent relationship with him.

As isolated, ontological beings, for example, we seldom talk about the sin of our nation-state as our sin. When we discuss the sin of our nation-state, instead, we usually think that the sin of our nation-state is totally unrelated to our individual sins. Let us think of war in Iraq. As we criticise the Bush administration's war in Iraq, for instance, we criticise those who are directly involved in making such foreign policies, overlooking its citizens who elected the Bush administration and allowed it to adopt such destructive foreign policies. On the other hand, as we take blame upon something other than us such as the Bush administration with relation to war in Iraq we feel that we are acquitted of the charge of waging such an unjustifiable war.

A theological anthropology seeing human beings as isolated, ontological beings allows people to have such justification of innocence. Firstly, the anthropology enables people to legitimately reject their responsibility, because they have no responsibility for such a war in which they are not directly involved. Because people have no responsibility, they are not obliged to challenge an unjustifiable war. The unjustifiable war, therefore, remains unchallenged. Secondly, it enables people to justify their innocence by blaming something other than themselves, such as the Bush administration, because as isolated, ontological beings they can easily assert their disconnection with such an administration. Rejecting our responsibility and blaming something other than ourselves, we can hardly address such a structural $\sin$ as the US imperialism. A theological anthropology that regards human beings as isolated, ontological beings thus is inappropriate to address such a structural sin. A different theological anthropology is requested.

\section{A new perspective on sin in the light of concrete totality}

An alternative theological anthropology is the concept of concrete totality, which is coined by Kosik (1976:50-56). Human beings as concrete totality can provide a basis for addressing structural sins, specifically, ever worsening inequality in a globalising world. Min (2004) puts a human being as concrete totality in the following way:

The being of a human person is not primarily that of an isolated soul, an individual subject, or an existential self who subsequently and accidentally enters into relations with others. It is primarily ontologically speaking - that of a being who finds oneself 'always and already' existing 'in' the world. This world [are] the cosmos, ... social relations, $\ldots$ and $\ldots$ family relations ... The human person is indeed a self but not a 'worldless' self. It is a self intrinsically constituted and permanently conditioned ... by this 
network of cosmic, social, and familial relations ... The human being is a 'concrete totality' of these constitutive relations: a 'totality' because it is an internally united whole, not an external collection, of such relations; and 'concrete' because it is a whole internally differentiated and historically developing by virtue of the internal tensions and contradictions among the differentiated elements. (pp. 102-103)

Min clarifies that a human being is not just an isolated, existential self. A human being is also a self that is socially, historically and ontologically conditioned. Put differently, a human being is an interconnected, ontological self. With the understanding of human beings as concrete totality, exclusively individualistic view of $\sin$ is inadequate. Let us compare sin of an isolated, ontological being with that of an interconnected, ontological being. For an isolated, ontological being, social and structural sins have no importance; only brokenness of individual relationship with her ontological foundation, that is, God, is of great concern to her. For an interconnected, ontological being, on the other hand, both social, structural sins and broken relationship with God are interconnected and inseparable.

In a globalising world, the worsening injustice ushered by intensified interdependence can be addressed not by the conception of a human being as an isolated, ontological self but by the concept of a human being as concrete totality: Whilst an isolated, ontological self can be legitimately indifferent to the worsening injustice, an interconnected, ontological being is obliged to care about such injustice.

Considering a human being as concrete totality, there arises a question: Is there a purely individual sin? Putting it differently, is there a sin that does not affect others, in an intensified, interdependent world? I would say that it is theoretically possible but practically impossible. In our normal life, our broken relationship with God cannot help but affect people interdependent upon us. Saint Augustine (2009) indicates such a characteristic of sin, referring to the love of self, which leads to the love of rule (p. 430). The love of rule can be translated as 'the lust for domination (libido dominandi)' (Chambers 2013:21). Not loving God leads to the lust of domination instead of serving one another. Saint Augustine at least assumes that individual sin of rulers is directly connected to domination of others. That is to say, individual sin is inseparable from sins to others. In our days, we understand that power is not external to our identities; rather, power constitutes our identities themselves (Mouffe 2000:21). Power is deeply ingrained in our relationship. Not only rulers but also all people have power over others. In that sense, the lust for domination is not exclusively for those in power. The commons will experience the lust for domination as they reject loving God. In other words, even purely individual sin affects one's relationship with others, unless she lives in seclusion.

The concept of a human being as concrete totality raises another question: How deeply is an individual affected by her given society? There is no one who selects her ethnicity, nationality and economic status, before she is born. Every human being is born into a certain society. How then is the relationship between group identity and individual identity? The importance of group identity is evident through Arendt's (1968) view on group identity: 'We are not born equal; we become equal as members of a group on the strength of our decision to guarantee ourselves mutually equal rights' (p. 181). What she says is that we become a human being as we have a group identity, specifically, a state identity. Arendt (1968) emphasises it in this way:

If a human being loses his political status, he should, according to the implications of the inborn and inalienable rights of man, come under exactly the situation for which the declarations of such general rights provided. Actually the opposite is the case. (p. 180)

According to Arendt, if we lose our group identity, we lose our basic human rights, not to mention equal rights. Benhabib (2004) puts Arendt's view this way:

Statelessness, or the loss of nationality status, she argued, was tantamount to the loss of all rights. The stateless were deprived not only of their citizenship rights; they were deprived of any human rights. (p. 50)

Individual human rights is meaningless if a person loses her group identity, specifically, her nation-state identity. Arendt shows that how vulnerable a human being without her group identity is. It is no exaggeration to say that a group identity protects an individual identity. Individual identity exists on the basis of a group identity.

The importance of a group identity leads an individual human being to a dilemma. A group identity can protect individual human beings within the group, but it creates out-group individual human beings and allows infringement of out-group human rights. As long as one is in a group, she is protected; however, as soon as she belongs to an outgroup, she becomes vulnerable. It is a tyranny of collective identity. Nazism, which Arendt experienced, exemplifies a tyranny of collective identity. In a globalising world, tyranny of collective identity abounds: tribal conflicts, domestic warfare and regional hatred, to name a few. In our days, a salient example of a tyranny of collective identity is imperialism. A tangible imperialism is that of the United States. In what follows, I will discuss how a tyranny of collective identity is persistently working throughout the history of the United States.

\section{Collective sin in nation-state building of the United States}

Imperialism can be understood in many different ways. One definition of imperialism is 'an extension of the sovereignty of (a nation-state) beyond (its own boundary)' (Hardt \& Negri 2000:xii). Imperialism of the United States means tyranny of collective identity, which justifies expelling Native Americans for its territorial expansion and rejecting immigrants for the protection of its own interest (Min 2017:580). 
Imperialism of the United States, according to Behdad (2006) can be understood by a phrase, 'retreat from truth to omnipotence' (pp. 4-5). Retreat from truth to omnipotence is a psychological term proposed by John Steiner. According to Steiner, when a person cannot distort or misrepresent her painful truth any longer, she becomes an omnipotent figure who does whatever she wants to do and justify whatever she has done. When she committed something morally wrong, she believed that she did not do it but the wrong thing inflicted on her (Steiner 1990:233-234). In the same vein, the United States forgets its brutal extermination of Native Americans but justifies such extermination and ignores its discrimination and rejection of immigrants but propagates itself as a nation of immigrants. The United States retreats from truth to omnipotence through its forgetfulness and unjustifiable claims. Let us see how the United States has retreated from truth to omnipotence throughout its history. I will discuss the history of the United States in order to show that tyranny of collective identity is not an aberration but a persistent phenomenon of the United States.

The United States started building its nation-state with its brutal extermination of Native Americans. The United States, however, forgot such brutality. According to Renan (1990) such forgetfulness of brutality is indispensable for nationstate building (p. 11).

The fact that a nation-state begins with its brutality means that any nation-state has an original sin from a Christian perspective. Nation-state as a coercive system brutally excludes those who disagree with such a coercive system. Every nation-state, however, is inclined to forget its brutal beginning. Forgetting its brutal beginning, the United States justifies its occupation of North America, asserting that Native Americans are inadequate to live in the land. One of the thoughts that justifies expulsion of and genocide of Native Americans is the concept of land, which is different from rude soil. Behdad (2006) explained it as follows:

Following Locke's Second Treatise of Government, the American claims the land as his property by mixing his labor with it. In this narrative, America is not a paradise found but a wild and primitive stretch of earth in need of cultivation. The soil is now described as infertile and rude, and it is the farmer's labor, cultivation, and therefore rightful possession of the land that constitute his freedom and power. (p. 41)

Rendering a soil into a land that needs cultivation, founders of the United States could justify their occupation and hide their brutal removal of Native Americans from the cultivated land. Tocqueville (2000) even says that Native Americans:

[S]eem to have been placed by Providence amidst the riches of the New World to enjoy them for a season, and then surrender them ... [T] he whole continent ... seemed prepared to be the abode of a great nation, yet unborn. (p. 28)

Tocqueville gives us a peaceful image of Native Americans' evacuation and European colonialists' occupation of North America. Referring to divine providence, Tocqueville justifies
Europeans' occupation of North America, without indicating brutal beginning of the United States.

Tocqueville (2000) further says that Native Americans are unable to acquire civilisation because they do not cultivate soil; what is worse, they regard labour as shame: '[T]hey consider labor not merely as an evil, but as a disgrace; so that their pride prevents them from becoming civilized, as much as their indolence' (p. 28). Native Americans are represented as indolent and labour-hating people, who cannot help but live in the woods. But, the inappropriateness of Native Americans to civilisation is insufficient to explain their disappearance. Considering that war and hunting is a worthy occupation for Native Americans, it is difficult to understand their peaceful disappearance in North America (Tocqueville 2000:397). Behdad (2006) says that Tocqueville's view 'minimises their genocide at the hands of European colonisers by attributing it to the failure of the indigenous population to cultivate the land' (p. 41). In other words, European colonisers are mainly responsible for their genocide. In Tocqueville's contention, thus, hiding truth and blaming out-group are evident.

What Tocqueville does is a salient example of retreat from truth to omnipotence. It is an undeniable fact that European colonisers in their nation-state building wiped out Native Americans. In order to reject the fact of Native American genocide, European colonisers (founders of the United States) asserted that land is given to those who cultivate it and accordingly they blamed Native Americans as indolent and labour-hating people for losing their lands. In that way, the truth that European colonisers massacred Native Americans is hidden; omnipotence that European colonisers are morally innocent but Native Americans are blamable comes to the fore. In this way, Tocqueville's narrative reveals retreat from truth to omnipotence.

The pattern of retreat from truth to omnipotence is recurrent in dealing with immigrants. According to Behdad (2006):

The benevolent discourse of immigration in the United States is a stereotypical discourse that reproduces the cliché of newcomers as huddled masses only to shore up such exclusionary sentiments as national pride and patriotism, while reaffirming America's exceptionalism. Xenophilia is thus entailed in xenophobia, just as hospitality toward immigrants involves a certain degree of hostility toward them. (p. 77)

The benevolent discourse of immigration means that the United States is a nation-state, which accepts the oppressed and refugees of the world. Such a benevolent discourse allows the United States to retreat from truth, as it hides the harsh treatment of immigrants. As the benevolent discourse of immigration is accepted as a truth-claim and new immigrants are recognised as huddled masses, citizens regard themselves as exceptionally good people but new immigrations as defective others. Although citizens are responsible for socioeconomic injustice against new immigrants, they blame new immigrants for such injustice, regarding themselves as benevolent people: It is not our 
problem but theirs. Blaming others is another type of retreat from truth to omnipotence.

In general, in terms of social ills blames were poured out exclusively on immigrants. Immigrants were made scapegoats for the US social ills. Handlin (1951) explained how the American social scientists have dealt with social ills in relation to immigrants:

The American social scientist approached their subject through the analysis of specific disorders: criminality, intemperance, poverty, and disease. Everywhere they looked they found immigrants somehow involved in these problems. In explaining such faults in the social order, the scholar had a choice of alternatives: these were the pathological manifestations of some blemish, either in the nature of the newcomers or in the nature of the whole society. It was tempting to accept the explanation that put the blame on the outsiders ... [T] he sociologists had accepted the dictum that social characteristics depended upon racial differences, [pointing out] that flaws in the biological constitution of various groups of immigrants were responsible for every evil that beset the country - for pauperism, for the low birth rate of natives, for economic depressions, for class divisions, for prostitution and homo-sexuality, and for the appearance of city slums. (p. 278)

According to Handlin, the American social scientists found faults with immigrants for social ills. Immigrants were biologically inferior others who were responsible for every evil. The tyranny of collective identity estranges out-group people, blames them and instead asserts innocence of ingroup people.

Chinese immigrants, for example, had been one of biologically inferior out-groups. Chinese were discriminated from the beginning of their immigration. The Chinese Exclusion Act of 1882 disallows Chinese immigrants. Even after the Chinese Exclusion Act of 1882, the Chinese were mocked as groveling worms (Higham 1975:25). Whilst some of European immigrants were discriminated, all Chinese immigrants were rejected and discriminated (Higham 1975:25). Chinese immigrants were permanent aliens because citizenship had not been given to them (Alba \& Nee 2003:200). What is worse, Chinese immigrants 'as nonwhites' 'could not testify in court' (Alba \& Nee 2003:200). They were not allowed to protect themselves. Chinese immigrants were almost non-beings or sub-human beings. In terms of treating Chinese immigrants, the United States was similar to Nazis, except for the fact that there was no concentration camp. Biologically inferior race is an unjustifiable concept, but it was prevalent for at least two centuries in the United States: it reveals retreat from truth.

Whilst some immigrant groups such as Chinese immigrants were portrayed biologically inferior people, immigrants in general were presented as politically, hygienically and economically inappropriate people to the United States. Immigrants were portrayed as politically inferior and inadequate people to the United States. Thomas R. Whitney asserts with boldness that immigrants are harmful to the political system of the United States. In justifying political inadequateness of immigrants to the US political system, Whitney first denies that all people are equal. Whitney (1856) says:

American Republicanism recognizes the principle that all men are created on a moral, political and social equality but it does not recognize the principle that all men reach the condition of manhood, having within them the same moral, political and social capacities. To declare that would be to declare a palpable absurdity. (p. 42)

Denying equality of every people, Whitney contends that naturalisation of immigrants, which allows equal rights to immigrants, is suicidal for the United States (1856:149).

Immigrants are described as a political threat to the United States: Immigrants have a latent intention of subverting the basic political system of the United States. Whitney (1856) adds unqualified political capacity of immigrants:

Whatever the natural or acquired rights of foreigners in the United States may be, they are certainly unqualified to govern the American people, and generally incapable of understanding the principles upon which the American Republic is constructed. (p. 150)

According to him, immigrants are unable to understand the US political system. What is worse, Whitney (1856) denies the possibility of immigrants to be accustomed to the United because 'to believe that a mass so crude and incongruous, so remote from the spirit, the ideas and the customs of America, can be made to harmonise readily with the new element into which it is case, is, to say the least, unnatural.' (p. 165)

Immigrants are depicted as political others totally different from citizens of the United States. Furthermore, immigrants are equated with Native Americans who were unable to adjust to political system of the United States. As Native Americans were expelled, immigrants have the same destiny, whether they are to be rejected or deported.

To justify rejection of immigrants, Whitney denies their equal human rights, portrays them as subversives and refutes their ability to adapt to the US political system. Tyranny of collective identity abuses political conceptions and justifies rejection of immigrants.

Immigrants in general are not allowed to land in the United States. There is, however, a class of people who are eligible to immigrate into the United States. Whitney (1856) divides immigrants into four classes: men of business, capital and respectability; red republicans, agrarians and infidels; papists; paupers (p. 168). Whitney contends that the first class, which takes no interest in politics, is acceptable to the United States. But, the other three groups are either to be accepted with restrictions or to be rejected. This selective acceptance is always there in the US immigration history to allow a small number of upper-class immigrants but reject majority of lower-class immigrants. The small number of selected group of people is a persistent theme in the US immigration policy. It will be discussed here in the section of economic justification of rejecting immigrants. 
Tyranny of collective identity takes a form of hygienics. There had been such nativism that renders immigrants as politically and socially inappropriate to the United States. In the late nineteenth century, according to Behdad (2006), there was a 'shift in the discourse of nativism from ideology to health'; this shift was possible because 'profession of medicine gained tremendous authority in the United States and became a significant factor in the nation's immigration policy' (p. 131). Hygienists openly assert that new patriotism is to get rid of physical or mental illness. Reed (1913) says, 'Greater is the need and grander the opportunity to live for one's country, and wage war against the powers of ignorance, indifference, disease and degeneracy' (p. 313). War against other nations is transformed into war against disease and degeneracy. War against disease and degeneracy can have many different forms such as strengthening public healthcare system, developing new medicines or investing medical research, to name a few. However, war against disease and degeneracy is directly connected to blaming immigrants. War against disease and degeneracy becomes war against immigrants. Terence V. Powderly shows the connection between disease and immigrants and the danger of immigrants' ruling over citizens of the United States through the disease. Powderly (1902) asserts three different arguments: disease comes with the oppressed, the disease of the oppressed assaults citizens of the United States and the oppressed becomes oppressor over citizens of the United States (p. 175). The Emergency Quota Act of 1921 is the very example in which these theories were officially implemented (Atkinson 2017). Each of the three arguments needs its own justification, respectively, because disease may or may not come with the oppressed, the disease of the oppressed may or may not assault citizens of the United States and the oppressed may or may not become oppressors over citizens of the United States. Without providing justification of the arguments, Powderly presents them as if they have a logical consequence. The three arguments, however, are not logically connected: even if disease comes with the oppressed, it may or may not assault citizens; even if the disease assaults citizens, the oppressed may or may not become oppressors of citizens. Without providing logical connection amongst the arguments, Powderly blindly asserts that the oppressed will take over the United States through their disease. Without legitimate justification, Powderly defines immigrants as disease carriers and subversives of the United States. Tyranny of collective identity hides truth but fabricates a distorted image of immigrants with relation to physical disease.

Not only physical disease but also mental illness is used to justify rejection of immigrants. In other words, immigrants are the cause of mental illness and of physical illness. Reed (1913) warns citizens of the possibility that mental defectiveness of immigrants will bring about serious ill effect to the United States by identifying immigrants with mental illness carriers who will bring about unrecoverable destruction to the Unites States (p. 325). Referring to Dr. T. W. Salmon, Reed (1913) says 'that more than $80 \%$ of the immigrants found on arrival to be mentally defective or insane are headed for that state' (p. 326). If more than $80 \%$ of immigrants are mentally ill, immigrants will exert a huge mentally ill effect on citizens in such a way that mental illness prevails over the United States. In this vein, immigrants' entrance should be rejected. Based on identification of immigrants with carriers of physical and mental illness, Reed (1913) justifies rejection of 'unsound' immigrants' entry and their deportation (p. 338). Considering that immigrants are either physically ill or mentally ill and more than $80 \%$ of immigrants are mentally ill, almost all immigrants are unsound people who are either rejected or deported.

Behdad (2006) characterises hygienic exclusion of immigrants as pseudoscientific nativism (p. 134). Based on scientific determinism (in reality, based on pseudoscientific knowledge), tyranny of collective identity allows citizens of the United States to turn a blind eye to real truth, regard immigrants as the cause of physical, social and mental disease, and accordingly justify exclusion and deportation of immigrants.

In our days, nativism of the United States, based on economic reasons, asserts that immigrants are inadequate to the economic system of the United States. One of the well-known scholars who advocate more restrictive immigration policy is George J. Borjas. I will argue that his view on immigrants shows retreat from truth to omnipotence.

Borjas (1999) introduces 'the top 10 symptoms of immigration', three of which I will discuss: There is a strong link between national origin and economic performance, immigrants harm the least skilled citizens and ethnic ghettos prevent immigrants from escaping from their enclaves (pp. 6-15).

Firstly, Borjas (1999) asserts that economic performance is closely related to national origin (pp. 9-10). According to him, immigrants from Europe and Canada or from Australia and South Africa show better economic performance than those who are from Latin America. The decisive factor of immigrants' economic performance for him is how much money immigrants earn in comparison with citizens. Borjas contends that because Latin American immigrants earn less money than those from Europe, Canada, Australia or South Africa, Latin American immigrants show worse economic performance. Although contending that national origin is strongly related to economic performance, he does not consider geographical proximity of Latin America to the United States and demand for unskilled, low-wage labour in the Southwest and California, which border on Mexico. In order to assert that national origin is the crucial factor of economic performance, Borjas ignores the fact that there are 'more than 75000 (Mexican) professionals, a relatively large contingent compared with other foreign-groups', although it is only $2.6 \%$ of foreign-born Mexican immigrants (Alba \& Nee 2003:188). Borjas hides information that does not support his view that certain ethnic groups are innately incompetent. 
Secondly, Borjas (1999) contends that immigration harms the least skillful citizens (pp. 10-11). He says that 'immigration seems to have been an important contributor to the rise in income inequality in the United States, depressing the economic opportunities faced by the least skilled workers' (Borjas 1999:11). He is correct in saying that unskilled immigrants contribute to the rise in income inequality in the United States. But, it is unclear whether immigrants encroach economic opportunities of the least skilled citizens. He contends that immigrants took jobs of the least skillful citizens, referring to the statistics that '[T]he typical native works in a job that has 4.6 injuries per 100 workers annually, whilst the typical immigrant works in one that has 4.4 injuries' (Borjas 1999:80). Borjas' evidence of the argument that immigrants took jobs of the least skilled citizens is that there is similar percentage of working injuries. His justification of the argument is meaningless because similar percentage of working injuries does not prove similar working conditions; similar percentage of working injuries does not show severity of injuries, which may prove similarity of working conditions; it is unknown, in addition, whether immigrants report their injuries as many as citizens do. His evidence of the argument, however, can hardly prove that immigrants and the least skillful citizens are working under similar working conditions. Accordingly, there is no reason to say that immigrants harm the least skillful citizens. Borjas, however, blames immigrants for unemployment of the least unskilled citizens.

Thirdly, Borjas argues that ethnic ghettos prevent immigrants from escaping from their enclaves. He means that ethnic enclave delays and prevents immigrants' assimilation to mainstream of the United States; those who live in a disadvantaged ethnic enclave will perpetuate their disadvantaged socio-economic life from generation to generation (Borjas 1999:14-15). That is to say, those unskilled immigrants have no hope to improve their lives. Richard Alba and Victor Nee challenge Borjas' pessimistic view on ethnic enclave. Alba and Nee (2003) consider ethnic enclave as 'a springboard for entry into professional occupations by the second and third generation' (p. 236). Alba and Nee agree that there is delayed assimilation or failed assimilation of the first generation of immigrants. But, they differ from Borjas, in the sense that ethnic enclave helps later generations to have better socio-economic life in the United States. Excluding the positive role of ethnic enclave, Borjas justifies his pessimistic view on ethnic enclave and perpetual socioeconomic disadvantaged life of immigrants in such an enclave. Borjas tries to show that unskilled immigrant workers are harmful both to themselves and to the United States.

Borjas' three arguments demonstrate retreat from truth. He uses the limited, distorted and unsustainable knowledge to support his arguments that national origins are strongly linked with economic performance, immigrants are harmful to the least skilled citizens and immigrants will perpetually reside in isolated, socio-economically disadvantaged enclaves. He has the reason of such retreat from truth: Immigration policy of the United States should '(maximize) the economic well-being of native-born population' (Borjas 1999:6). In other words, immigrants should be rejected as long as they do harm to well-being of citizens of the United States, without regard to well-being of those who try to immigrate into the United States. In order to maximise the economic well-being of US citizens, Borjas proposes immigrants policy that favours skilled immigrants. Such an immigration policy proposal is resonant with Whitney's first class: those who benefit the United States such as skilled workers are appropriate immigrants. It also reveals retreat to omnipotence: Borjas absolutise his nation-state, the United States, which selects skilled immigrants for its own sake, without regard to other nation-states' socio-economic wellbeing.

\section{Concluding reflection}

I have shown that tyranny of collective identity is evident in imperialism of the United States. Tyranny of collective identity of the United States chooses a useful tactic to justify its imperialism: retreat from the truth to omnipotence. The United States hides its brutal removal of Native Americans as it introduces the concept of land of which only cultivators have the ownership and portrays Native Americans as indolent, labour-hating people. When it comes to immigrants, they are presented as the biologically inferior, politically inappropriate people to the political system of the United States, hygienically dangerous groups to citizens of the United States, or people who are economically detrimental to the economy of the United States. Imperialism of the United States justifies such exclusion of Native Americans and immigrants through retreat from truth to omnipotence. The retreat from truth to omnipotence is not an aberration in the history of the United States. Rather, it is a persistent phenomenon of a nation-state, the United States. The persistent retreat from truth to omnipotence is a concretised form of tyranny of collective identity. Tyranny of collective identity cannot be addressed by exclusively individualistic understanding of $\mathrm{sin}$. In the light of exclusively individualistic understanding of sin, tyranny of collective identity is not discernable. As long as Christian faith is unable to discern tyranny of collective identity, it is unintentionally backing such tyranny: it perpetuates injustice caused by a group identity. If Christian faith understands sin in the light of human being as concrete totality, however, tyranny of collective identity is no longer foreign to Christian faith. Rather, tyranny of collective identity becomes a salient sin of human beings, which should be addressed through Christian faith. As a case of grave sin of human beings, retreat from truth to omnipotence should be challenged and changed in such a way that human beings recover from omnipotence to truth. Considering persistency of tyranny of collective identity, it is urgent to have an understanding of sin in the light of human beings as concrete totality. 


\section{Acknowledgements Competing interests}

The author has declared that no competing interests exist.

\section{Author's contribution}

I declare that I am the sole author of this research article.

\section{Ethical considerations}

This article followed all ethical standards for a research without direct contact with human or animal subjects.

\section{Funding information}

This research received no specific grant from any funding agency in the public, commercial or not-for-profit sectors.

\section{Data availability}

Data sharing is not applicable to this article as no new date were created or analysed in this study.

\section{Disclaimer}

The views and opinions expressed in this article are those of the author and do not necessarily reflect the official policy or position of any affiliated agency of the author.

\section{References}

Alba, R. \& Nee, V., 2003, Remaking the American mainstream: Assimilation and contemporary immigration, Harvard University Press, Cambridge, MA

Arendt, H., 1968, Imperialism: Part two of the origins of totalitarianism, A Harvest Book, New York, NY.
Atkinson, D.C., 2017, 'What history can tell us about the fallout from restricting immigration', TIME, viewed 23 December 2020, from https://time.com/4659392/ history-fallout-restricting-immigration/.

Augustine, 2009, The city of God, transl. M. Dods, D.D., Hendrickson Publishers, MA.

Behdad, A., 2006, A forgetful nation: On immigration and cultural identity in the United States, Duke University Press, Durham, NC.

Benhabib, S., 2004, The rights of others: Aliens, residents and citizens, Cambridge University Press, New York, NY.

Borjas, G.J., 1999, Heaven's door: Immigration policy and the American economy, Princeton University Press, Princeton, NJ.

Chambers, K., 2013, 'Slavery and domination as political ideas in Augustine's city of God', The Heythrop Journal 54(1), 13-28. https://doi.org/10.1111/j.1468-2265. 2010.00612.x

Handlin, O., 1951, The uprooted: The epic story of the great migrations that made the American people, Little, Brown and Company, Boston, MA.

Hardt, M. \& Negri, A., 2000, Empire, Harvard University Press, Cambridge, MA

Higham, J., 1975, Strangers in the land: Patterns of American nativism 1860-1925, Atheneum, New York, NY

Kosik, K., 1976, Dialectics of the concrete: A study on problems of man and world, transl. H. Dordrecht, D. Reidel Pub. Co., Boston, MA.

Min, A., 1989, Dialectic of salvation: Issues in theology of liberation, State University of New York Press, New York, NY.

Min, A., 2004, The solidarity of others in a divided world: A postmodern theology after postmodernism, T \& T Clark International, New York, NY.

Min, A., 2017, 'Sin, grace, and human responsibility: Reflections on justification by faith alone in the age of globalization', Neue Zeitschrift für Systematische Theologie und Religionsphilosophie 59(4), 572-594. https://doi.org/10.1515/ nzsth-2017-0033

Mouffe, C., 2000, The democratic paradox, Verso, New York, NY.

Powderly, T.V., 1902, 'Immigration's menace to the national health', North American Review 175(548), 50-60.

Reed, A.C., 1913, 'Immigration and the public health', Popular Science Monthly 83(October), 320-338.

Renan, E., 1990, 'What is a nation', in H.K. Bhabha (ed.), Nation and narration, pp. 8-22, Routledge, New York, NY.

Steger, M.B., 2003, Globalization: A very short introduction, Oxford University Press, New York, NY.

Steiner, J., 1990, 'The retreat from truth to omnipotence in Sophocles' Oedipus at Colonus', International Review of Psycho-Analysis 17(2), 227-237.

Tocqueville, A., 2000, Democracy in America, transl. H. Reeve, Bantam Books, New York, NY.

Whitney, T.R. 1856, A defence of the American policy: As opposed to the encroachments of foreign influence and especially to the interference of the encroachments of foreign influence and especially to the interference of the
papacy in the political interests and affairs of the United States, DeWitt \& papacy in the political 